\title{
Iron and Manganese in Groundwater of Rrogozhina Aquifer, Western Albania
}

\author{
Suada Luzati ${ }^{1}$, Arjan Beqiraj ${ }^{2}$, Enkeleida Beqiraj Goga ${ }^{2}$ and Olgert Jaupaj $^{3}$ \\ 1. Department of GIS, Centre of Agricultural Technology Transfer, Fushe Kruje 1502, Albania \\ 2. Department of Earth Sciences, Faculty of Geology and Mining, Str. "Elbasani"-Tirana 1021, Albania \\ 3. Dpartment of Geoinformatics, Albanian Geological Survey, Str "Myslym Keta”, Tirana 1045, Albania
}

\begin{abstract}
This paper aims to advance previous studies on the iron and manganese content in groundwater of Rrogozhina aquifer (western Albania) and to show the factors which control the content of both iron and manganese in groundwater of this aquifer. Rrogozhina aquifer represents an important groundwater source of the country whose relevance was highly increased during recent years because of the demographic expansion in this region. This is a typically multi-layered artesian aquifer which consists of sandstone and conglomerate with high heterogeneous permeability. The groundwater mostly belongs to $\mathrm{HCO}_{3}-\mathrm{Mg}-\mathrm{Ca}$ hydrochemical type. The content of soluble iron and manganese in groundwater ranges from $0.004 \mathrm{mg} / \mathrm{L}$ to $0.7 \mathrm{mg} / \mathrm{L}$, and from $0.0 \mathrm{mg} / \mathrm{L}$ to $1.147 \mathrm{mg} / \mathrm{L}$, respectively. Deeper the groundwater occurs and longer the distance from the recharge zone, higher is the content of $\mathrm{Fe}^{2+}$ in groundwater due to gradual depletion of $\mathrm{O}_{2}$ in groundwater. The content of iron is higher than that WHO and EU recommended, which were $21 \%$ and $25 \%$ respectively, while the content of manganese were $17 \%$ and $23 \%$, respectively. Abstraction of groundwater with high quantities by deeper wells would be accompanied by increase of dissolved iron and manganese content in groundwater which should be treated (with aeration) in order to decrease the content of these two elements in the water before using it.
\end{abstract}

Key words: Generalized Rrogozhina, iron, manganese, aquifer, groundwater.

\section{Introduction}

The Rrogozhina aquifer spreads out over the Albanian pre-Adriatic depression, where it covers an area of $2,100 \mathrm{~km}^{2}$, and is mainly composed of Pliocene sandstone and conglomerate intercalated with impermeable clay layers. Its basement consists of impermeable clays of Miocene molasses and the aquifer is covered by Quaternary formations represented by alluvial (sandy clay, silt, silty sand, sand, gravel and pebbles), marshy (loam, clay, silt, sand and decomposed organic material) and marine (mostly sand) sediments [1]. The aquifer of Rrogozhina is typically multilayered and is shapedunder artesian conditions [2]. The high number of hydrogeological drillings that were generated during the last 50-60 years showed that the sandstone and conglomerate layers are rich in

Corresponding author: Arjan Beqiraj, professor, Ph.D., main research fields: hydrochemistry and environmental sciences. groundwater. Many authors studied this aquifer aiming to clarify its lithology, stratigraphy, structure $[1,3]$, hydrogeological features $[2,4]$ and the groundwater quality $[5,6]$. The permeability of the aquifer is extremely variable due to variation in lithology, particle size of medium and extent of compactness of the water-bearing layers [2]. This was also confirmed by the lack of an inverse correlation between low values of Total Dissolved Solids (TDS) and corresponding high hydraulic conductivity (C) [4]. The groundwater of Rrogozhina aquifer mostly belongs to $\mathrm{HCO}_{3}-\mathrm{Mg}-\mathrm{Ca}$ hydrochemical type because of a magmatic-carbonatic mineralogical composition of the water - bearing sandstones and conglomerates, which, in turn, is responsible for the high content of iron and the presence of manganese in the groundwater. Both the hydrochemistry of the groundwater and its iron and manganese content show variable values over the aquifer extension because of heterogeneous 
mineralogical and lithological composition of aquifer medium. In general, sandstone-related groundwater hashigher iron content against the groundwater from conglomerate $[7,8]$.

\section{Material and Methods}

57 groundwater samples from wells, 3 sandstone and 2 conglomerate samples from outcrops, were taken. Water for chemical analysis of iron and manganese was directly sampled in the artesian wells, while in semi-artesian ones it was either sampled by pump or using the SEBA Liquid Sampler KLL-S. Sand, silt and clay fractions of samples were obtained by sieve and hydrometric methods (ASTM C775-79, 1989).

The mineralogical composition of the sand fraction was studied by optical microscopy and portions weighting. Thin sections were studied using LeitzWetzlar microscope.

Chemical analysis are made in Chemical Laboratory of the Geological Survey of Albania. Fe and Mn were analyzed in Atomic Absorber Spectroscopy (AAS) "PERKIN ELMER" in both flame technic 400 AANALYST and 900 AA model with graphite furnace.

\section{Geological and Hydrogeological Features}

The aquifer of Rrogozhina extends over the western pre-Adriatic depression of Albania (Fig. 1) covering an area of 2,100 $\mathrm{km}^{2}$. The water-bearing sandstones and conglomerates belongs to Pliocene molassic formations, which is composed of two packages [1]: the lower part, known as Helmesi suite, is a most-clay section, whereas the upper part is represented by sandstone and conglomerate intercalations of the Rrogozhina formation. The geological section of thelater in the southern sectors consists mainly of sandstones, whereas northward its extension, the conglomerates dominate [2]. The conglomerate and sandstone of Rrogozhina formation outcrop along the hill slopes while in the plain areas are covered by Quaternary sediments of alluvial, marshy and marine type, which consist of clay, sandy clay, silt, silty sand, sand, gravel and pebbles. The degree of compactness of Rrogozhina formations is very different, ranging from freely to very strongly cemented sandstones and conglomerates [9]. The thickness of Rrogozhina formation ranges from 1,000 $\mathrm{m}$ (Rrogozhina outcrop) to $1,700 \mathrm{~m}$ fromthe center of the Karavasta syncline (Fig. 2). The neotectonic movements have intensively affected the molassic formations [4].

The vast $\left(2,100 \mathrm{~km}^{2}\right)$ extension, thick (over $100 \mathrm{~m}$ ) water, bearing section and wide outcrops of the sandstones and conglomerates (1/4 of aquifer extension), makes this aquifer important for potable water supply forthe rural and urban communities that habit within the territories of the aquifer extension. The Rrogozhina aquifer is a multilayered aquifer that shapedunder typically artesian conditions. This later is conditioned by the following factors: (1) sandstones and conglomerates are intercalated with impermeable clays; (2) they construct syncline forms; (3) recharge zones have higher quota then discharge ones [4]. The sandstones and conglomerates show very heterogeneous permeability due to their different lithological composition, variable particle size, different extent of their compactness, type of the cement, etc. The sandstones that spread over the southern part of the Rrogozhina aquifer have lower (2.05-3.0 $\mathrm{m} /$ day) hydraulic conductivity, than conglomerates (2.56-4.0 m/day), which spread over the northern part where those of Durresi area have the highest $(4.0 \mathrm{~m} /$ day) permeability [9]. Such a complex lithology of the aquifer medium has conditioned an extremely variable yield of the wells [2]. The Rrogozhina aquifer is characterized by a dual porosity; the prevailing one isfracture porosity, but inter-granular porosity is present as well. The locally increased permeability of conglomerate aquifer layers is explained with the enlargement of the rock's fissures by the solution of carbonate cement [9]. As a consequence, the conglomerate has higher trasmissivity (Tmean = $78-134 \mathrm{~m}^{2} /$ day $)$ then sandstone $\left(\right.$ Tmean $=45-97 \mathrm{~m}^{2} /$ day) and among conglomerates those of Durresi area show distinctly higher and more stable transmissivity values [9]. 


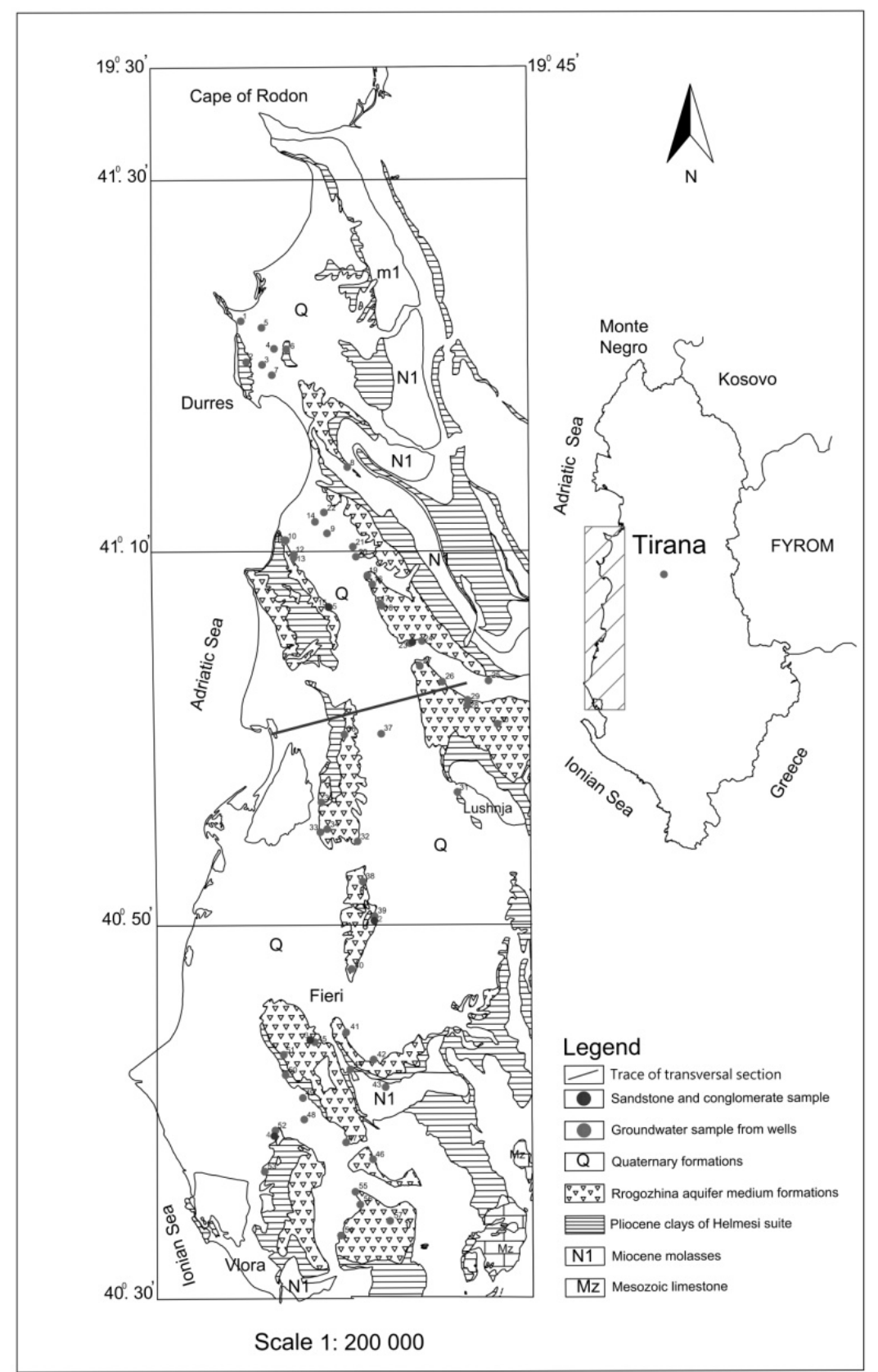

Fig. 1 Schematic geological map of Rrogozhina aquifer (location of water and soils samples is shown).

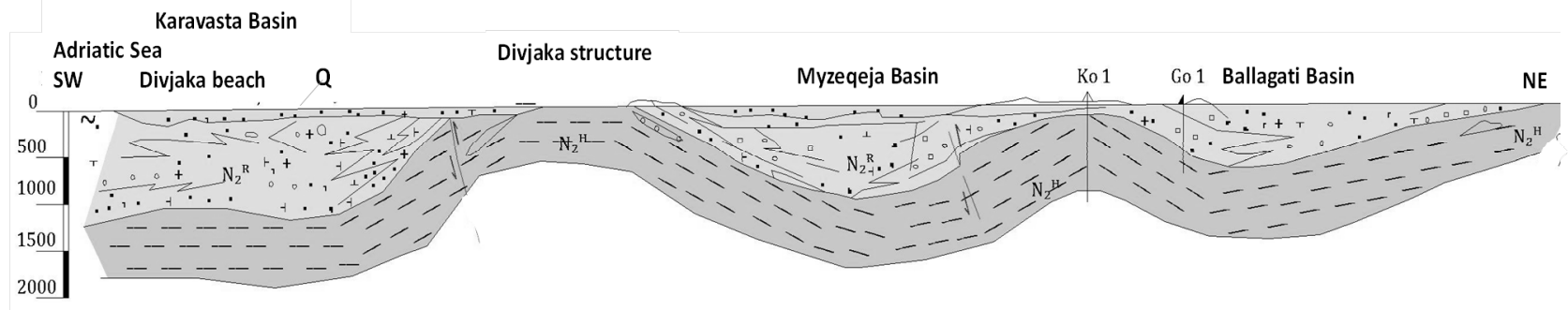

Fig. 2 Transversal section of molassic formations in the Karavasta-Ballagat region (Q-Quaternary sediments; ${ }^{\mathrm{H}}{ }^{\mathrm{H}}$-Pliocene clays of Helmesi suite; $\mathrm{N}_{2}{ }^{\mathrm{R}}$-Rrogozhina formations. 


\section{Geochemical Characteristics of Groundwater}

The groundwater shows a relatively variable geochemical composition due to vast extension of the aquifer, variable geological and hydrogeological features, as well as relationships with boundary aquifers and seawater, relations of the tested groundwater with respect to recharge and discharge zone and possibly the depth of wells $[4,6]$. However, the mainly magmatic - carbonatic mineralogical composition of the water - bearing sandstones and conglomerates has determined a geochemical composition of groundwater consisting mostly of $\mathrm{HCO}_{3}-\mathrm{Mg}$-Ca hydrochemical type (Fig. 3). Such a geochemical composition characterizes the groundwater of Rrogozhina aquifer as chemically immature to intermediate groundwater, which mainly plots near the center of the Piper plot [10]. Dissolution of minerals seems to be the major geochemical process in the formation of the groundwater composition. Other hydrochemical types are less important and are mainly related with the $\mathrm{Na}$ enrichment in water through cation exchange processes between groundwater and clay formations that are more abundant over the plain extension of the aquifer. The above mainly magmatic composition of sandstones and conglomerates is also responsible for the high content of iron in the groundwater of this aquifer which occurs as $\mathrm{Fe}^{2+}$ due to the lack of $\mathrm{O}_{2}$ [11-13]. Iron content is higher in sandstone related groundwater where the silt fraction is mainly composed by iron-bearing minerals such as magnetite, epidote, granate, sphene, amphibole and pyroxene [7]. In general, the wells are drilled down to $250 \mathrm{~m}$. The values of TDS and general hardness of groundwater pumped from these wells range from 500 $\mathrm{mg} / \mathrm{L}$ to $800 \mathrm{mg} / \mathrm{L}$ and from 11 to $25^{\circ} \mathrm{dH}$, respectively. At the $\mathrm{pH}$ 's commonly encountered in groundwater $(\mathrm{pH}=7.0-8.5), \mathrm{HCO}_{3}^{-}$is the dominant carbonate species. In general, up to the above drilled depth, all the hydrochemical parameters of the groundwater fit the Albanian and EU limits for the potable water. In some cases, $\mathrm{NH}_{4}{ }^{+}, \mathrm{SO}_{2}, \mathrm{Cl}^{-}$, etc. are found in concentrations higher than the limits of drinking water. In the diagram (not shown) of TDS versus well depth $(\mathrm{H})$ was found that groundwater can maintain TDS values less that 1.0 $\mathrm{mg} / \mathrm{L}$ up to a depth that ranges from $400 \mathrm{~m}$ to $500 \mathrm{~m}$ according to the well position with respect to recharge and discharge zone [4].

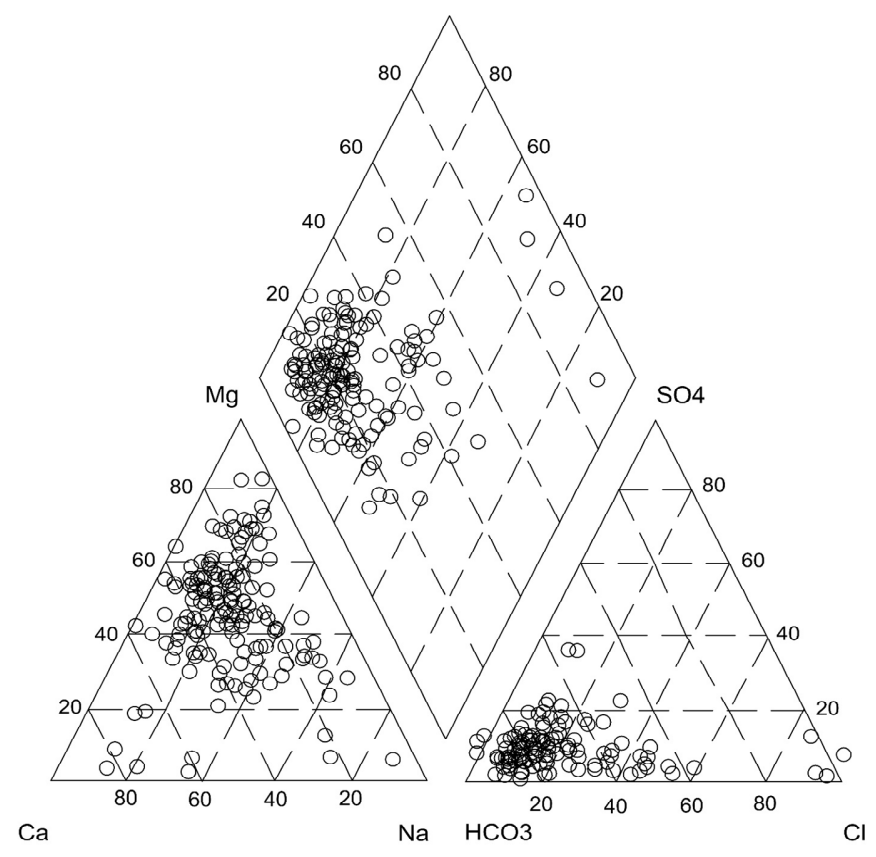

Fig. 3 Piper diagram of Rrogozhina aquifer hydrochemical composition (data from Ref. [4]) 


\section{Results and Discussion}

\subsection{Iron and Manganese in Groundwater}

The content of iron in groundwater ranges from $0.004 \mathrm{mg} / \mathrm{L}$ to $0.7 \mathrm{mg} / \mathrm{L}$ having an average value of $0.13 \mathrm{mg} / \mathrm{L}$ and deviation standard around it of 0.20 (Table 1), while manganese varies from $0.0 \mathrm{mg} / \mathrm{L}$ to $1.147 \mathrm{mg} / \mathrm{L}$ having an average value of $0.08 \mathrm{mg} / \mathrm{L}$ and a deviation standard around it of 0.25 (Table 1).

In groundwater, iron and manganese existas reduced divalent cations $\left(\mathrm{Fe}^{+2}\right.$ and $\left.\mathrm{Mn}^{2+}\right)$ which are soluble in water [14, 15]. In cases, where surface water doesn't seep into groundwater directly because of the less impermeable strata like clayey soils, groundwater usually contains less dissolved oxygen and iron,but contains manganese in large quantities [16]. The dissolved ferrous iron represents the only oxidation state of iron that was found in Rrogozhina groundwater because of the completely confined conditions of the aquifer that, on the other hand, have absolutely prohibited any possible exposure of water to oxygen [7].

Fluctuations of oxygen content of groundwater that relate to iron and manganese content, correlate to some extent with the distance of sampled water from the recharge zone. The long $(>20 \mathrm{~km})$ distance between the recharge and discharge zones along with low (0.3-2.5 m/day) permeability of the medium has caused

Table 4 Model content of Fe and Mn in sampled groundwater from Rrogozhina aquifer.

\begin{tabular}{|c|c|c|c|c|c|c|c|}
\hline No. sample & Welldepth (m) & $\begin{array}{l}\mathrm{Mn} \\
(\mathrm{mg} / \mathrm{L})\end{array}$ & $\begin{array}{l}\mathrm{Fe} \\
(\mathrm{mg} / \mathrm{L})\end{array}$ & No. sample & Welldepth (m) & $\begin{array}{l}\mathrm{Mn} \\
(\mathrm{mg} / \mathrm{L})\end{array}$ & $\begin{array}{l}\mathrm{Fe} \\
(\mathrm{mg} / \mathrm{L})\end{array}$ \\
\hline 1 & 200 & 0.003 & 0.067 & 30 & 122 & 0.003 & 0.030 \\
\hline 2 & 80 & 0 & 0.257 & 31 & 250 & 0.017 & 0.150 \\
\hline 3 & 145 & 0.477 & 0.091 & 32 & 280 & 0.020 & 0.190 \\
\hline 4 & 100 & 0.113 & 0.319 & 33 & 90 & 0.004 & 0.030 \\
\hline 5 & 128 & 0.035 & 0.391 & 34 & 150 & 0.005 & 0.030 \\
\hline 6 & 105 & 0.252 & 0.08 & 35 & 104 & 0.006 & 0.029 \\
\hline 7 & 170 & 0 & 0.03 & 36 & 110 & 0.025 & 0.020 \\
\hline 8 & 140 & 0.032 & 0.008 & 37 & 120 & 0.010 & 0.010 \\
\hline 9 & 237 & 1.147 & 0.035 & 38 & 250 & 0.016 & 0.37 \\
\hline 10 & 110 & 0.410 & 0.022 & 39 & 95 & 0.010 & 0.02 \\
\hline 11 & 120 & 0.047 & 0.023 & 40 & 80 & 0.004 & 0.02 \\
\hline 12 & 120 & 0.021 & 0.004 & 41 & 95 & 0.009 & 0.13 \\
\hline 13 & 200 & 0.016 & 0.004 & 42 & 85 & 0.025 & 0.03 \\
\hline 14 & 120 & 0.011 & 0.006 & 43 & 150 & 0.017 & 0.56 \\
\hline 15 & 80 & 0.952 & 0.046 & 44 & 95 & 0.006 & 0.03 \\
\hline 16 & 250 & 0.037 & 0.007 & 45 & 87 & 0.006 & 0.01 \\
\hline 17 & 85 & 0.121 & 0.010 & 46 & 100 & 0.014 & 0.12 \\
\hline 18 & 270 & 0.016 & 0.004 & 47 & 101 & 0.007 & 0.33 \\
\hline 19 & 85 & 0.047 & 0.006 & 48 & 70 & 0.002 & 0.03 \\
\hline 20 & 115 & 0.068 & 0.415 & 49 & 80 & 0.039 & 0.03 \\
\hline 21 & 90 & 0.026 & 0.476 & 50 & 90 & 0.006 & 0.02 \\
\hline 22 & 110 & 0.205 & 0.009 & 51 & 120 & 0.008 & 0.19 \\
\hline 23 & 180 & 0.024 & 0.660 & 52 & 78 & 0.021 & 0.01 \\
\hline 24 & 75 & 0.014 & 0.500 & 53 & 70 & 0.017 & 0.01 \\
\hline 25 & 70 & 0.004 & 0.03 & 54 & 70 & 0.012 & 0.02 \\
\hline 26 & 105 & 0.003 & 0.02 & 55 & 50 & 0.067 & 0.02 \\
\hline 27 & 110 & 0.006 & 0.04 & 56 & 70 & 0.016 & 0.01 \\
\hline 28 & 90 & 0.032 & 0.700 & 57 & 1500 & 0.03 & 0.09 \\
\hline 29 & 360 & 0.021 & 0.680 & & & & \\
\hline
\end{tabular}


a gradual depletion in $\mathrm{O}_{2}$ and a respective enrichment in $\mathrm{Fe}^{2+}$ and $\mathrm{Mn}^{2+}$. Thus, groundwater of wellsdistant from discharge zone (no. 1-7) has higher average values of iron and manganese $(0.176 \mathrm{mg} / \mathrm{L}$ and 0.126 $\mathrm{mg} / \mathrm{L}$, respectively) than those near the recharge zone (no. $12-18)$ that have lower average values $(0.006 \mathrm{mg} / \mathrm{L}$ and $0.037 \mathrm{mg} / \mathrm{L}$, for Fe and $\mathrm{Mn}$, respectively).

In addition, the time factor also plays a crucial role. Longer time residence of the groundwater in $\mathrm{Fe}^{2+}$ and $\mathrm{Mn}^{2+}$ favored their enrichment. More iron (and/or manganese) enters into solution as the age of groundwater increases because they tend to be released progressively from the geological materials. In fact, Beqiraj, et al. [4] found that deeper the groundwater occurs and longer the distance from the recharge zone, generally higher the content of $\mathrm{Fe}^{2+}$ would be in groundwater due to the longer time of groundwater residence in the aquifer.

The relationship between iron and manganese under increasing $\mathrm{pH}$ and redox potential (Eh) suggests that ferrous iron $\left(\mathrm{Fe}^{2+}\right)$ normally occurs in the area with lower redox potential and within the $\mathrm{pH}$ range of 5.5 to 8.2. This also means that $\mathrm{Fe}^{2+}$ is more easily and rapidly oxidized than $\mathrm{Mn}^{2+}$. The latter is often occurring with $\mathrm{Fe}^{3+}$ under $\mathrm{pH}$ values larger than 8 and redox potentials between 420 millivolts to 790 millivolts. Above this redox potential, the stable form of $\mathrm{MnO}_{2}$ is found [15].

There is not any evidence of increasing oxidation state of $\mathrm{Fe}$ and $\mathrm{Mn}$ with increasing the value of $\mathrm{pH}$ probably due to the narrow $(7.3-8.7 ;$ [4]) range of $\mathrm{pH}$ values of Rrogozhina groundwater. For the same reason, i.e. narrow range of temperature values variation, there is not found any temperature-dependence oxidation rate of $\mathrm{Fe}$ and $\mathrm{Mn}$.

As it may be seen in Fig. 4, about $25 \%$ of analyzed samples have higher Fe than European Union (EU) recommended levels, while $21 \%$ of them have higher Fe relative to World Health Organization (WHO) standard. Considering the content of Mn (Fig. 5), about $23 \%$ of analyzed samples have higher content than EU recommended values, but $17 \%$ of them have higher values than WHO standard. Because the sampling of groundwater was casual from private wells drilled mostly on the aquifer outcrops or near them, the above values of the dissolved iron and manganese in groundwater could be considered as the lowest ones. In general, higher water quantities can be extracted from deeper wells, but this is accompanied by an increase of content of Total Dissolved Solids (TDS) [17] and a respective increase in dissolved iron and manganese contents as indicated by the positive correlation in the diagrams of iron content versus depth of well and TDS values (not shown). A treatment, probably water aeration, aimed to lower the content of dissolved iron and manganese in groundwater should be considered in order to avoid possible unpleasant consequences like black sludge, staining, clogging of pipe, etc..

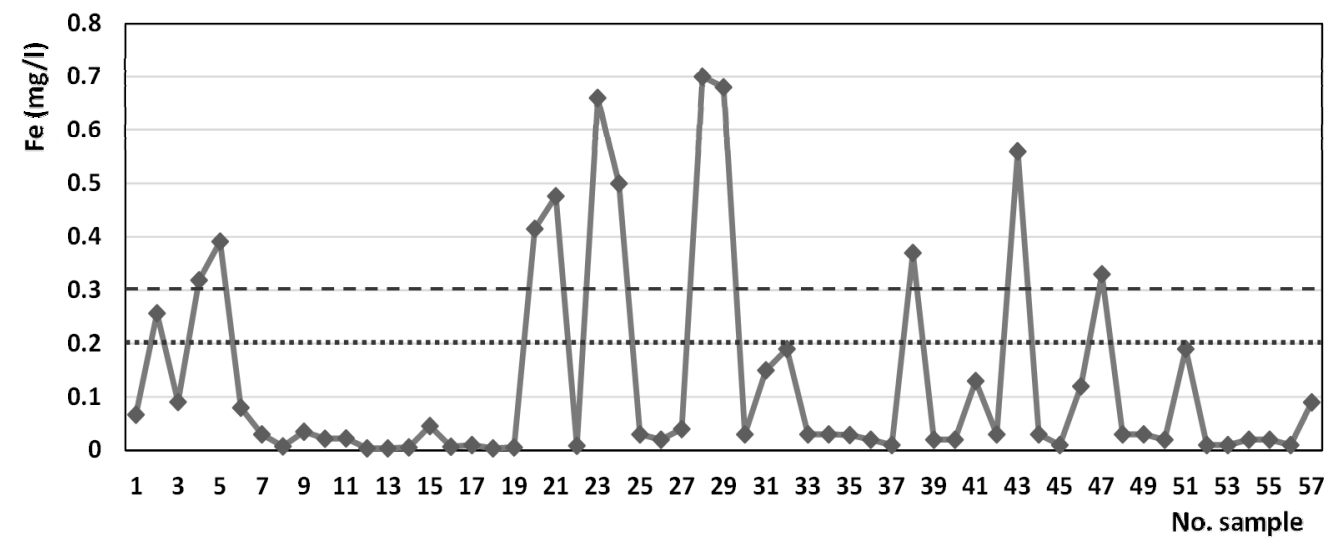

Fig. 4 Variation of Fe content in the sampled Rrogozhina groundwater (Red dashed and dotted line represent WHO (1996) and European Union (1998) recommended values, respectively). 


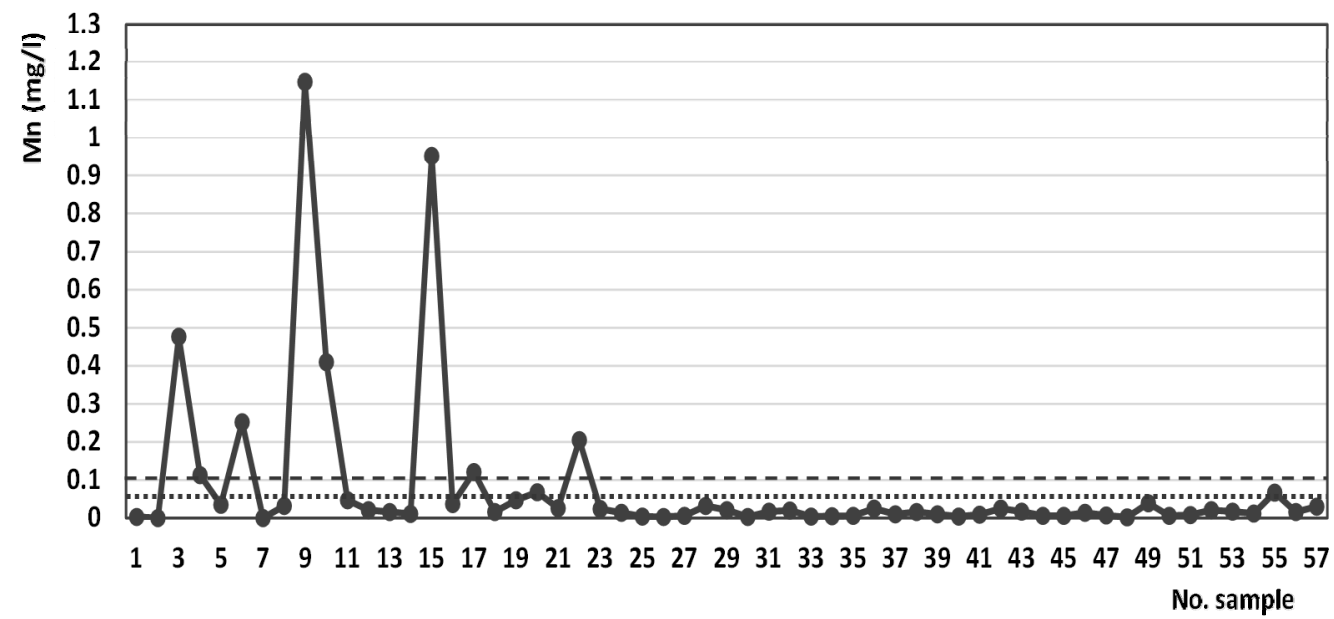

Fig. 5 Variation of Mn content in the sampled Rrogozhina groundwater (Red dashed and dotted line represent WHO (1996) and European Union (1998) recommended values, respectively).

\subsection{Mineralogy and Geochemistry of the Aquifer Medium}

Natural sources of iron and manganese may include weathering of iron and manganese bearing minerals like silicates, iron sulphide and iron rich clay minerals. In order to have a complete view of the mineralogical composition of the aquifer medium, all its particle fraction were studied. The pebbles and gravels are petrographically represented by gabbro, volcanics, limestone, chert, sandstone, etc. (Photo 1).

In the sandy fraction are found, among other mineral grains, several iron-bearing minerals like chlorite, hematite and magnetite (Photo 2). The presence of native sulfur is an indication of the presence of casual reduction conditions in the aquifer.

Besides sample no. RR-1, the other samples show bulk chemical composition similar with that of a basalt (Table 2). This is true, if the authors accept that average chemical composition of sedimentary rocks equals the average chemical composition of the altered rocks which were eroded and transported to be deposited in a basin [18], like this of Pre-Adriatic depression where molasses were formed.

The first source of iron should be from chamosite and ankerite; this suggestion is supported by the positively strong correlation of $\mathrm{FeO}$ with $\mathrm{MgO}(\mathrm{R} \approx 0.7)$ (Fig. 6). The second source would be from oxides (hematite and magnetite) and the third should be from iron— bearing clays.

\section{Conclusions}

The Rrogozhina aquifer is a multi-layered aquifer that occurs under typically artesian conditions and shows very heterogeneous permeability which has conditioned very extremely variable yield of the wells. The groundwater shows a relatively variable geochemical composition where $\mathrm{HCO}_{3}-\mathrm{Mg}-\mathrm{Ca}$ hydrochemical type dominates. TDS value of groundwater remains less that $1.0 \mathrm{mg} / \mathrm{L}$ up to a depth of 400-500 m.Content of iron in groundwater ranges from $0.004 \mathrm{mg} / \mathrm{L}$ to $0.7 \mathrm{mg} / \mathrm{L}$, while manganese varies from $0.0 \mathrm{mg} / \mathrm{L}$ to $1.147 \mathrm{mg} / \mathrm{L}$. Both occur as soluble reduced divalent cations $\left(\mathrm{Fe}^{2+}\right.$ and $\left.\mathrm{Mn}^{2+}\right)$ in water because the completely confined conditions of the aquifer have absolutely prohibited any possible exposure of water to oxygen.

Deeper the groundwater occurs and longer the distance from the recharge zone, higher is the content of $\mathrm{Fe}^{2+}$ in groundwater due to the longer time of groundwater residence in the aquifer.

Of analyzed samples, about $21 \%$ to $25 \%$ of $\mathrm{Fe}$ and $17 \%$ to $23 \%$ of $\mathrm{Mn}$ have higher contents than that WHO and EU recommended, respectively. Water with higher quantities can be extracted from deeper wells, 

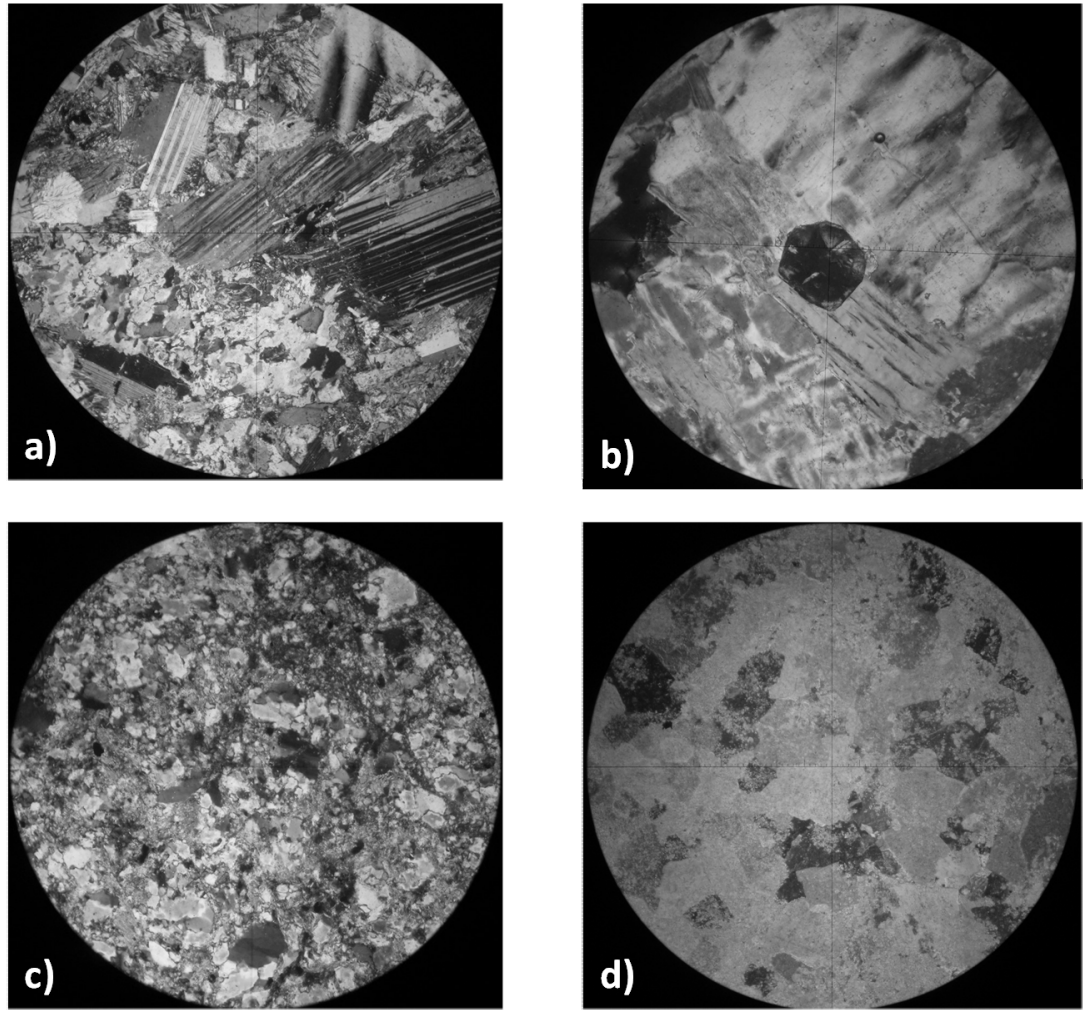

Photo 1 Selected thin sections of pebble fraction (a-porphiric gabbro; b-granate-bearing amphibolite; c-quartz-mica sandstone; d-micritic limestone).
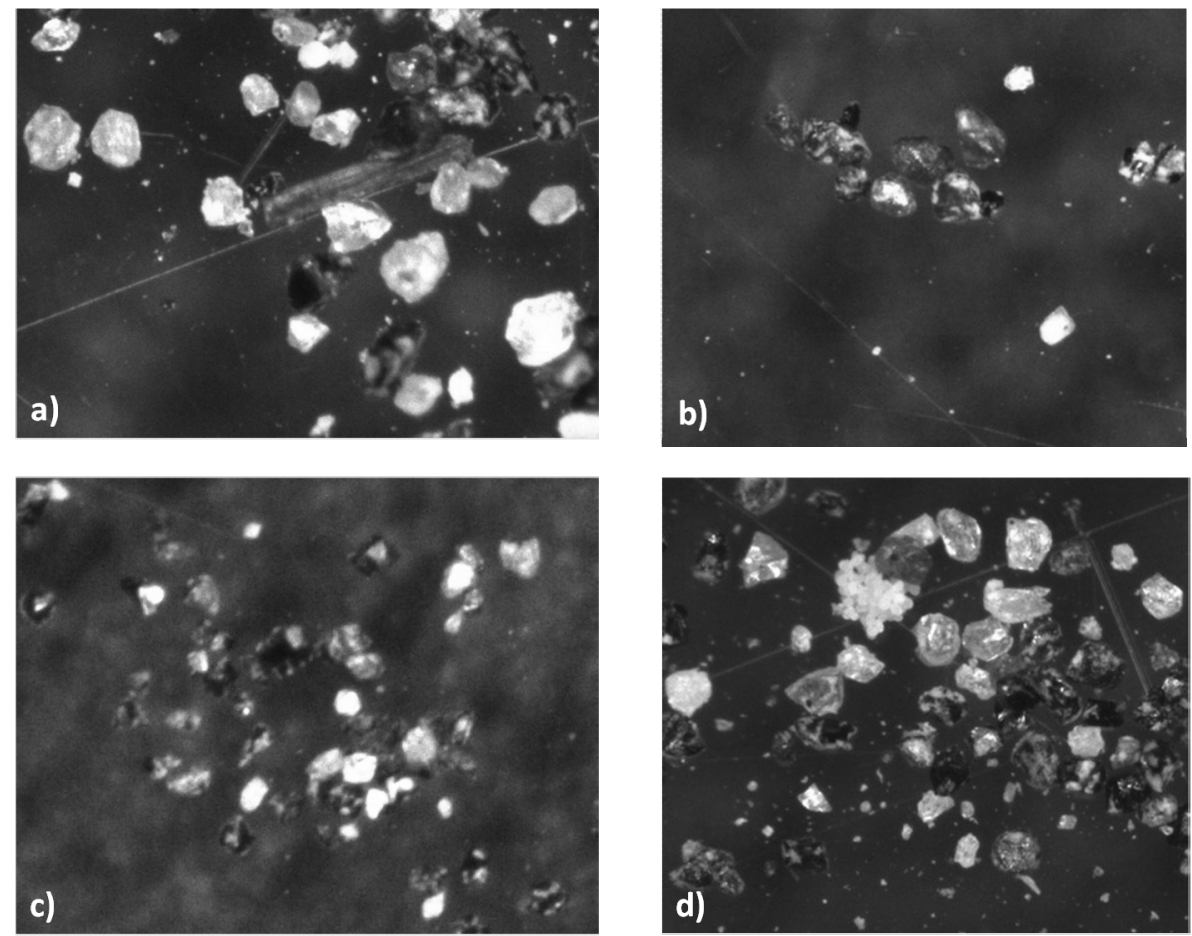

Photo 2 Selected mineral sandy grains under the microscope (a-green chlorite; b-reddish hematite; c-black magnetite; d-yellow sulfur). 
Table 2 Chemical composition of silt-clay fraction (in $\mathrm{wt} \%$ ).

\begin{tabular}{llllllllllll}
\hline No sample & $\mathrm{SiO}_{2}$ & $\mathrm{Al}_{2} \mathrm{O}_{3}$ & $\mathrm{Fe}_{2} \mathrm{O}_{3}$ & $\mathrm{FeO}$ & $\mathrm{TiO}_{2}$ & $\mathrm{CaO}$ & $\mathrm{MgO}$ & $\mathrm{MnO}$ & $\mathrm{Na}_{2} \mathrm{O}$ & $\mathrm{K}_{2} \mathrm{O}$ & $\mathrm{LOI}$ \\
\hline $\mathrm{RR}-1$ & 27.05 & 4.43 & 4.72 & 1.15 & 0.20 & 29.01 & 5.35 & 0.1 & 0.30 & 0.30 & 27.05 \\
$\mathrm{RR}-2$ & 58.12 & 7.80 & 4.60 & 1.01 & 0.55 & 8.40 & 6.70 & 0.09 & 0.72 & 0.65 & 10.88 \\
$\mathrm{RR}-3$ & 44.01 & 10.68 & 9.73 & 0.72 & 0.55 & 9.67 & 6.50 & 0.22 & 0.55 & 0.60 & 16.36 \\
$\mathrm{RR}-4$ & 55.6 & 9.70 & 5.43 & 1.08 & 1.45 & 9.10 & 4.60 & 0.13 & 0.78 & 0.63 & 10.72 \\
$\mathrm{RR}-5$ & 50.05 & 6.34 & 10.76 & 0.72 & 0.57 & 9.25 & 7.81 & 0.18 & 0.54 & 0.40 & 13.24 \\
\hline
\end{tabular}

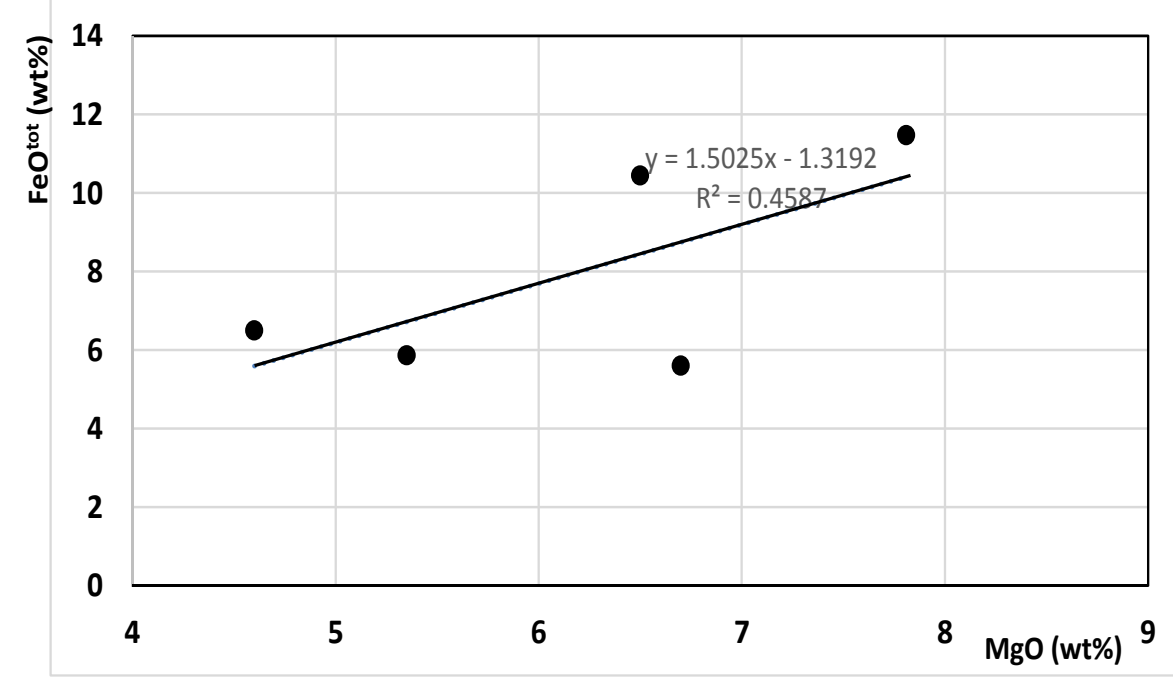

Fig. 6 Diagram of $\mathrm{FeO}$ versus MgO contents in the silt-clay fraction.

but this could be accompanied by an increase in dissolved iron and manganese content in groundwater.

\section{References}

[1] Hyseni, A. 1995. "Structure and Geodynamic Evaluation of Pliocene Molasses of Pre-Adriatic Depression." Ph.D. thesis, Polytechnic University of Tirana.

[2] Eftimi, R. 1984. Permeability Features of Rrogozhina Formation. Bulletin of Geological Sciences 3: 57-73.

[3] Beqiraj, A., Hyseni, A., Leka, G., and Mata, M. 2007. Geological-structural Aspects of the Rrogozhina Aquifer (Albanian Pre-Adriatic Depression)-Kosovo: The Workshop: Management of Geomining Resources.

[4] Beqiraj, A., Hyseni, A., Saraçi, M., Hoxha, I., Meshi, A., Prenjasi, E., et al. 2006. Assessment of Ground Water Quality and Quantity of in the Rrogozhina Acquifer as A Water Supply Potential Source for the Rural Zones within It. Report of Agency for Research, Technology and Innovation, Tirana, Albania.

[5] Beqiraj, A., and Kumanova, X., 2010. "Geochemistry of Groundwater of Rrogozhina Aquifer (Western Albania)." Presented at 7th ISEMG Symposium, Adana, Turkey.

[6] Luzati, S., Beqiraj, A. and Jaupaj, O. 2016. Groundwater Geochemistry of Rrogozhina Aquifer (Western Albania). EGE and Bul. of Geological Society of Greece,
Thessaloniki, Greece.

[7] Beqiraj, A. 2008. "High-iron Content Groundwater of Rrogozhina Aquifer-Effects of Sediment Mineralogy." In Proceedings of the 8th International Hydrogeological Congress, 213-218.

[8] Beqiraj, A. and Beqiraj, E. 2011. "Effects of Sediment Mineralogy to High-iron Content in the Groundwater of Rrogozhina Aquifer (Western Albania)." Studia UBB Geologia 56 (2): 25-30.

[9] Eftimi, R., 2002. "Hydraulic Parameters and Yield of Wells of Sandstone-conglomerate Aquifer of Rrogozhina Formation in Albania." Presented at 1st MEM WG Workshop on Hard Rock Hydrology, Tinos Island, Hellas.

[10] Allen, D. M., and Matsuo, G. P. 2002. Results of the Groundwater Geochemistry Study on Hornby Island, British Columbia. Final report, Victoria, BC.

[11] Christenbury, J. H., Plowman, F. T., Wagenet, L., and Lemley, A. 1990. Iron and Manganese. Mississippi: Cooperative Extension Service, Clemson University.

[12] Gruett, G. 1993. "Removing Problem Iron." Water Technology 16 (3): 48-51.

[13] Postma, D., and Brockenhuus-Schack, B. S. 1987. "Diagenesis of Iron in Proglacial Sand Deposits of Lateand Post-Weichselian Age." J. Sed. Petrology 57: 1040-1053. 
[14] Appelo, C. A. J., Postman, D. 1996, Geochemistry, Groundwater and Pollution. Rotterdam: CRC press.

[15] Silveria, L. 1988. "In situ' Groundwater Treatment." Encyclopedia of Life Support Systems (EOLSS). Groundwater III. Accessed September 25, 2011. http://www.eolss.net/Sample-Chapters/C07/E209-08 $-05 . p d f$.

[16] Hallberg, R. O., and Martinell, R. 1976. "Vyredox-In Situ
Purification of Groundwater." Groundwater 14 (2): 88-93.

[17] Luzati, S., Beqiraj, A. 2016. "Hydrochemistry of Rrogozhina Aquifer Groundwater." Bul. Shk. Gjeol: in press.

[18] Tashko, A. 2003. Geochemistry, Principles and Applications (in Albanian). Tirana: Polytechnic University of Tirana. 